\title{
The Choice of Funding Sources for Start-Ups in a Transitional Economy: The Ability to Predict in a National Context
}

\author{
Olga Obraztsova ${ }^{\text {a }}$ \\ Assistant Professor, Moscow School of Economics, olga_obraztsova@rambler.ru \\ Tatiana Poliakova ${ }^{\text {a }}$ \\ PhD Student, Chair of Statistics, Economic Faculty, tatyana-zabelova@yandex.ru \\ Ekaterina Popovskaya ${ }^{b}$ \\ Analyst, Laboratory of Entrepreneurship Research, epopovskaya@hse.ru \\ a Lomonosov Moscow State University, 1, bld. 46, Moscow 119234, Russian Federation. \\ b National Research University Higher School of Economics, 20, Myasnitskaya str, Moscow 101000, \\ Russian Federation.
}

\begin{abstract}
$\mathrm{D}$ espite the government's efforts to support entrepreneurship, the major share of startup funding in transitional economies comes from the owners' own funds and "love capital" rather than from institutional sources (banks, venture funds, etc.). This increases the asymmetry of information concerning the capabilities of the emerging businesses for potential investors, and thus hinders the development of entrepreneurship as a whole.

The paper considers the key determinants affecting the decisions made by entrepreneurial start-ups when choosing from a number of ways to finance their business in transitional economies. An attempt has been made to build models for an adequate prediction of the financial strategies of early entrepreneurs. A number of hypotheses have been put forward to verify external and internal factors influencing the financial choices of early entrepreneurs.

Hypotheses were tested on a survey sample of early entrepreneurs from seven transitional economies,

including Russia. The predictive values of the final models proved to be effective in predicting start-ups' financial strategies and in comparing the probability of early entrepreneurs borrowing capital.

Our findings confirm that the combinations of external and internal financing differ significantly depending on the national macroeconomic and social context. Given that simple borrowing mechanisms for supporting a business can lead to an undesirable tendency to avoid formal borrowed funds altogether, such behavior can hinder the development of entrepreneurship. The obtained results show that pessimistic short-term expectations about the conditions for entrepreneurship in a region aggravate this problem in Russia. The outcomes demonstrate a need to reduce the burden on start-up businesses and to improve entrepreneurial aspirations by encouraging confidence in a start-up's future and find the optimal proportion of borrowed sources in a business's capital structure.
\end{abstract}

Keywords: entrepreneurial activity; early entrepreneurs; financial choice factors; Fisher's linear discriminant; borrowed funds; love capital; cross-country comparisons; contextual approach.
Citation: Obraztsova O., Poliakova T., Popovskaya E. (2017) The Choice of Funding Sources for Start-Ups in a Transitional Economy: The Ability to Predict in a National Context. Foresight and STI Governance, vol. 11, no 3, pp. 71-81. DOI: 10.17323/2500-2597.2017.3.71.81 
$\mathrm{M}$ any experts see entrepreneurship as a driver of positive change in a country, and the foundation for balanced, sustainable growth of a market economy. In recent decades, providing support for entrepreneurship has become a priority for economic policy in most countries, especially those undergoing systemic transformation. This applies to Russia and other countries - the members of the Commonwealth of Independent States (CIS), and Central and Eastern European (CEE) nations.

A developed entrepreneurial sector typically indicates a high level of the national economy and its ability to adapt to changing market situations [Beck et al., 2008]. However, the determinants, structure, and dynamics of entrepreneurship in the context of economic restructuring and radical macroeconomic shifts are quite different from those in advanced economies with strong entrepreneurial traditions, long experience, and a stable socioeconomic and political environment.

In Russia, this new model of economic activity has emerged at a much slower rate than in many CEE countries, given the complete lack of relevant experience and theoretical knowledge. Conversely, in Hungary and Poland, a sufficiently strong private sector (which existed even before the beginning of the transitional period) served as a basis for the development of small and medium enterprises (SME).

Enterprise surveys conducted by the World Bank (World Bank Enterprise Surveys, WBES) [Yang et al., 2013] have revealed that in Russia the emergence of new companies and development of existing ones are hindered by three major institutional barriers: a complex taxation system, insufficient access to financial resources, and corruption. More than $15 \%$ of companies noted the inadequately developed financial system as the main hurdle, and, as a consequence, the lack of investment capital, which makes Russia to noticeably stand out among the 123 countries covered by the aforementioned survey.

Therefore, access to the necessary financial resources turns out to be among the more relevant issues. Numerous studies address it in the context of providing support to large corporations, on the basis of conventional corporate funding theories [Klapper et al., 2006; Beck et al., 2008]. Yet, the limited availability of investments hinders the development of small entrepreneurship even more, especially at the early stages. Over the last ten years, access to formal funding mechanisms has been steadily getting more difficult for entrepreneurs at the early stage of their firms' development. According to Global Entrepreneurship Monitor (GEM) data, in 2006 the share of institutional loans was 19\% higher than that of funds received through informal support. However, already in 2007, the situation had changed quite dramatically: only about $40 \%$ of the money invested in start-up companies came from official sources [Murzacheva, Obraztsova, 2008]. Subsequently, the above negative trends were exacerbated: the amount of loans that start-ups in transitional economies received as official investments did grow, but the number of entrepreneurs making do with "love capital" grew as well. As a result, the latter's share in the structure of early-stage entrepreneurs' capital is currently $35-40 \%$ greater than the amount of officially obtained funds. According to an expert poll conducted in the framework of the GEM, by the beginning of 2017, difficult access to official funding became the major hurdle not only hindering the development of entrepreneurship in transitional economies, but actually threatening its very survival [GERA, 2017].

The resulting structure of capital available to early-stage entrepreneurs, with the dominating shares of one's own resources and "love capital", increases the probability of default on the micro- and macroeconomic levels and slows down the development of entrepreneurship - despite the officially implemented support programs. This is primarily due to the fact that, according to the asymmetric information theory, the choice between external and one's own capital is a qualitative signal that businesses send to financial markets. It is particularly important for early-stage entrepreneurship because potential investors do not see prospects for its development.

Accordingly, we have tried to identify factors affecting early-stage entrepreneurs' choice of funding sources, and assess the predictability of such choices. Our analysis was based on a contextual approach and took into account the impact of country-specific socioeconomic conditions on the development of entrepreneurship in transitional economies. The microdata collected in the framework of the GEM project served as the empirical basis of this study.

The subsequent sections present the theoretical foundation of the study; put forward a number of hypotheses; describe the databases and empirical techniques; and summarize the results of the analysis, with a discussion. The final section formulates our main conclusions, and the applicability of the study results in terms of affecting the capital structure of early-stage entrepreneurship.

\section{Theoretical basis and hypotheses}

Many researchers [Yang et al., 2012; Chavis et al., 2011; Beck et al., 2008; Aidis, 2005; Levine, 2005; Djankov et al., 2002] believe that access to financial resources is the fundamental factor affecting the conditions for 
and strategy of starting a new business. Depending on the specific national context, this factor can either mobilize entrepreneurial activity or, conversely, create barriers hindering the launch of new enterprises. Despite the fact that bank-based SME funding formats and micro financing programs alike have been actively developing in all transitional economies over recent years, in many cases they still could not meet the companies' demand for resources. In most such countries, including Russia, an entrepreneur's own funds and "love capital" continue to dominate as sources of early-stage support, since they do not require economic returns and create fewer problems with confidence and repayment periods [Murzacheva, 2011]. Accordingly, by analyzing the specific features of early-stage entrepreneurship in the context of a transitional economy, particularly the conditions affecting start-up companies' choice of support providers, seems to be a relevant field of study in terms of increasing the effectiveness of government policies to support SMEs.

Factors affecting new companies' emergence and growth rates cannot be thoroughly analyzed due to the significant uncertainty of these processes, which is caused by a variety of factors. Still, it has been established that the success of entrepreneurial activities does depend upon external framework conditions, which in turn are affected by the economic, social, political, institutional, spatial, temporal, historical, and other contexts [Welter, 2011].

It has been proven that companies' capital structure and access to external funding sources depend on country-specific features [Antoniou et al., 2008]. Researchers in the area of entrepreneurship theory [Audretsch, Thurik, 2004; Levine, 2005; Yang et al., 2013; Chavis et al., 2011; Hashi, 2001; Shane, Wenkataraman, 2000; Glas et al., 2000; et al.] agree with this argument, and cite inadequate access to sources of sufficient investments among the factors limiting the creation of new companies. However, the authors of the above studies mainly focus on funding arrangements available to private companies in countries with an Anglo-Saxon market economy model, which typically feature developed and efficient capital markets and a high level of bank competition. On the other hand, in transitional economies, entrepreneurship faces considerable barriers and high transaction costs associated with obtaining access to capital (relevant markets began to emerge in CEE and CIS countries only in the early 1990s, and still remain rather undeveloped) [Gerasimova, 2012]. Therefore it would not be correct to directly extrapolate the conclusions about the specific features of funding for early-stage entrepreneurs in developed market economies to countries with transitional economies, including Russia.

The issues associated with providing support to entrepreneurship in transitional economies, and ways to deal with them remain at the center of many researchers' attention [Yang et al., 2012; Chavis et al., 2011; Beck et al., 2008; Aidis, 2005; Levine, 2005; Djankov et al., 2002]. However, no comparative studies of the effect of the national socioeconomic context on early-stage entrepreneurs' choice of specific funding sources have yet been conducted.

Klapper et al. [Klapper et al., 2006] established that in most of the 15 analyzed developing countries external funding was not particularly important to entrepreneurs (least of all in Ukraine). Limited access to resources can be explained not only by the low level of trust in early-stage entrepreneurs as economic agents, but also by a widespread sceptical attitude toward the very possibility of setting up and running a successful innovative company in post-socialist countries [Berger, Schaeck, 2010].

The probability of early-stage entrepreneurs' attracting external investments increases if their business idea is innovative and involves the production of goods or services new to the market. This factor appears to outweigh the fears of failure [Yang, 2012; Welter, Smallbone, 2011; Robb, Robinson, 2010].

Certain "rules of the game" for the entrepreneurial sector have by now been developed in countries with transitional economies. Firms at an early stage of their life cycle, which do not yet steadily generate revenues by selling the goods and services they produce, find it harder to get banks, investment companies, and venture funds interested [Murzacheva, 2011]. The inadequate legal and regulatory systems, a lack of transparency concerning lenders' solvency, and a negative social attitude toward entrepreneurship in general result in start-up companies' increased dependence on unofficial funding sources [Chavis et al., 2011]. The modernization of the legal system, more transparent credit history information, and the media promoting a positive image of entrepreneurship as a career would help make official investments more accessible to such businessmen.

A typical feature of financial capital markets for small entrepreneurs in Russia, and in the vast majority of CEE countries, is the lack of funding organizations' trust in private businesses. This trend is further aggravated by the insufficient transparency of financial markets, and the asymmetry of available information. Investors who have actually invested in a new company know more about it than other potential sources of support, and tend not to be too keen on sharing this information. Typically, they are more willing to invest in new firms established by entrepreneurs they know. As a consequence, many early-stage entrepreneurs who do not yet have credit histories have rather limited opportunities for securing loans [Black, 2009]. 


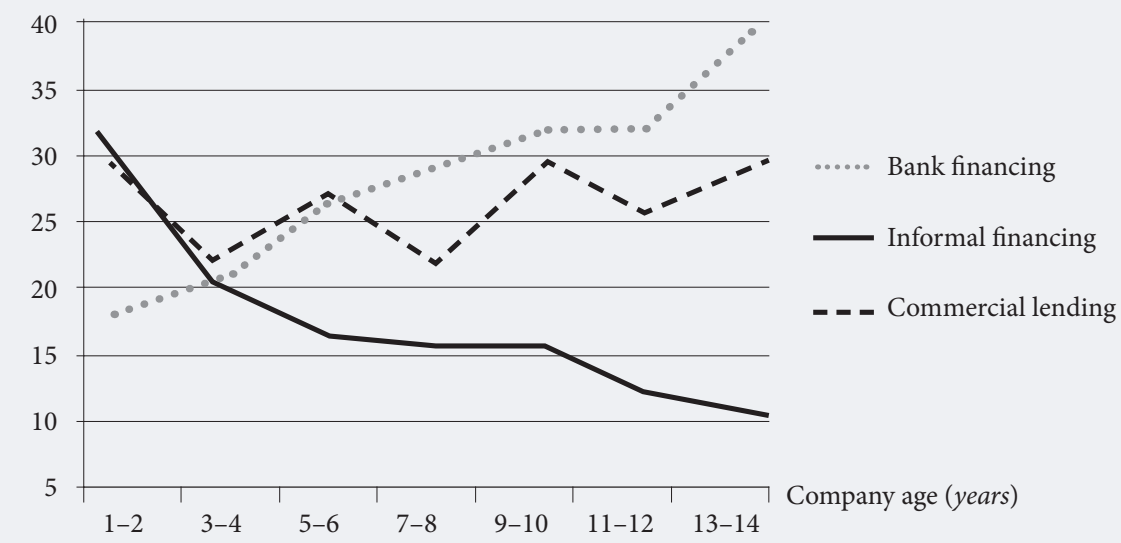

Source: [Chavis et al., 2011].

Accordingly, researchers break down the funding sources companies are most likely to find on the basis of these companies' development stage [Chavis et al., 2011]. According to the "pecking order" theory, established companies usually have higher profitability combined with partially exhausted growth potential, so they have more resources of their own (unallocated profits), which they primarily use. On the other hand, early-stage entrepreneurs have practically no such opportunities because it usually takes at least three years to reach the break-even point and begin making profits [Chavis et al., 2011]. In addition, a faultless reputation and a good credit history will help solve some of the funding problems created by asymmetrical information. Unlike early-stage firms, mature companies can get more favorable loan terms [Chavis et al., 2011]. Accordingly, the share of external investments, especially bank loans, in the capital structure of small companies is significantly smaller compared with that of larger businesses [Beck et al., 2008].

Apart from the lack of an established reputation and credit and trading histories, small companies also encounter problems when they try to obtain loans because they cannot provide loan security [Verheul, Thurik, 2001]. High interest rates and difficult terms turn into insurmountable obstacles for many early-stage entrepreneurs [Yang et al., 2013]. For example, a survey of 800 SMEs in Southeastern European countries (Bosnia and Herzegovina, Macedonia, Slovenia) revealed that the high costs of credit and loans was the most difficult hurdle to overcome, thus hindering the creation of new firms in Slovenia and Macedonia, though not in Bosnia and Herzegovina [Aidis, 2005]. Still, the lack of one's own resources and the insufficient appeal (or availability) of institutional investments for earlystage entrepreneurs increase the importance of informal sources, such as "love capital" and funding provided by business angels willing to support an idea by providing a loan [Yang et al., 2013].

Such funding sources, especially "love capital," are particularly attractive to young companies in transitional economies, including Russia. The situation changes as the companies grow and the number of their employees increases (Figure 1). To avoid bureaucratic and other institutional barriers, earlystage entrepreneurs do accept informal investments, though by doing so they risk facing problems like unreliability, the irregular provision of funds by friends and relatives, unprofessional assessments of their business ideas, and "significant non-monetary costs" [Djankov et al., 2002]. The correlation between early-stage entrepreneurs' choice of funding sources and the income level in the country is shown in Table 1. Having a stable financial market reduces entrepreneurs' dependence on external loans and promotes business activities in the economy at large [Robb, Robinson, 2010].

An analysis of the literature on the specific features of early-stage companies' funding in transitional economies allowed us to formulate several hypotheses:

Hypothesis 1: The set of factors affecting early-stage entrepreneurs' choice of funding sources depends on the national socioeconomic context.

Hypotheses 2-4: Early-stage entrepreneurs' choice of external funding sources in transitional economies is promoted by the following:

- A favorable institutional environment for starting one's own business; 
Table 1. Correlation between income level in the country and preferred sources of funding

\begin{tabular}{|l|l|}
\hline \multicolumn{1}{|c|}{ Income level (according to the World Bank classification) } & \multicolumn{1}{c|}{ Main sources of support for businesses } \\
\hline High or above average & Leasing \\
\hline Low & Informal funding \\
\hline All levels other than low & Active use of bank loans \\
\hline * Low-income countries typically have poorly developed financial systems and limited access to investments. \\
Source: composed by the authors, based on the data in [Djankov et al., 2002].
\end{tabular}

- Innovative business ideas, good prospects for marketing new products or services that prevail over fears of failure;

- The promotion of a positive image of entrepreneurship in the media.

\section{Initial data and methodology}

Our research is based on data collected as part of the GEM surveys. The GEM project is focused on developing common international methodological standards for monitoring, which would allow one to obtain a realistic picture of the state of entrepreneurship and the role it plays in various economies. Russia has participated in the GEM since 2006. In 2016, the survey covered more than 200,000 adult, able-bodied people in more than 100 countries $^{1}$. A standardized questionnaire ${ }^{2}$ is used to collect data in all participating countries. The results are integrated into a single bank of open, comparable data, and include information about entrepreneurial behavior at various stages: from the emergence of an idea to run an established business, which allows one to assess businessmen's financial strategies. The GEM microdata furthermore makes it possible to empirically analyze strategies employed by early-stage entrepreneurs who, due to various reasons, were missed by official statistics [Obraztsova, 2010].

According to the GEM methodology, early-stage entrepreneurs are divided into two groups [Reynolds et al., 2005]:

- nascent entrepreneurs, who fully or partially own their business and were actively setting it up over the course of the previous year, and if they did receive any income from it, it was only profitable for no more than three and a half months;

- new businesses owners (NBO), who received income from their companies over a period ranging between three and a half months to three and a half years.

According to the basic concept, the array of microdata about early-stage entrepreneurs in transitional economies was built using variables calculated on the basis of answers to the following questions:

- Q1A: Are you currently trying to set up a new business on your own or in partnership, which would stipulate self-employment or selling products/services to customers?

- Q1B: Are you currently trying to set up a new business on your own or in partnership, for your employer, in the course of performing your work? [Reynolds et al., 2005].

On the basis of the microdata collected in the scope of a representative survey using the above tool, a multistage stratified probabilistic sample was constructed for analysis purposes. To ensure its validity and compatibility with the characteristics of the general adult able-bodied population of the relevant countries, the sample data was weighted by the respondents' gender and age.

In line with the methodology presented in [Holm, 1979], country-specific data was made compatible, while annual values were tested for belonging to the overall general population (Spearman's correlation coefficient (rho), Holm-Bonferroni correction for multiple comparisons, $\alpha=0.01$ ). On that basis, by combining the databases for four years (2008-2011) for all countries, we put together the array of data for analysis. Combining the databases allowed us to analyze the dynamics of early-stage entrepreneurs' choice of funding sources by comparing various periods of the countries' socioeconomic development [Yang et al., 2013]:

- 2008: relatively high economic growth rates, mostly favorable conditions for entrepreneurship;

- 2009: the emergence of a full-scale financial and economic crisis in all European countries;

- 2010-2011: overcoming the acute phase of the crisis, eliminating its negative effects, the emergence of pre-requisites for economic growth, including in the entrepreneurial sector.

\footnotetext{
Available at: http://www.gemconsortium.org/country-profiles, accessed 12.10.2016.

${ }^{2}$ Available at: http://www.gemconsortium.org/data/sets, accessed 12.10.2016.
} 
Table 2. Variables used in the analysis

\begin{tabular}{|c|c|c|c|}
\hline № & Variable & Code & Value \\
\hline \multicolumn{4}{|c|}{ Criterion variable } \\
\hline \multirow{2}{*}{1} & \multirow{2}{*}{ Funding source } & \multirow{2}{*}{ OwnF_BorrF } & 0: One's own funds \\
\hline & & & 1: Borrowed funds \\
\hline \multicolumn{4}{|c|}{ Predictor variable } \\
\hline \multirow{3}{*}{1} & \multirow{3}{*}{ Education level } & \multirow{3}{*}{ Education } & $\begin{array}{c}\text { 1: Low (no or incomplete secondary, or incomplete } \\
\text { vocational education) }\end{array}$ \\
\hline & & & $2:$ Medium (secondary or vocational education) \\
\hline & & & 3: High (tertiary education) \\
\hline \multirow{2}{*}{2} & \multirow{2}{*}{$\begin{array}{l}\text { Know somebody personally who started a business } \\
\text { during over the past two years }\end{array}$} & \multirow{2}{*}{ KNOWEN } & 0: No \\
\hline & & & 1: Yes \\
\hline \multirow{2}{*}{3} & \multirow{2}{*}{$\begin{array}{l}\text { Expect favourable conditions for starting one's own } \\
\text { business to be in place in the area of residence in } \\
\text { the next six months }\end{array}$} & \multirow{2}{*}{ OPPORT } & $0:$ No \\
\hline & & & 1: Yes \\
\hline \multirow{2}{*}{4} & \multirow{2}{*}{$\begin{array}{l}\text { Possess the knowledge, qualifications, and skills } \\
\text { required to start a new business }\end{array}$} & \multirow{2}{*}{ SUSKIL } & $0:$ No \\
\hline & & & 1: Yes \\
\hline \multirow{2}{*}{5} & \multirow{2}{*}{$\begin{array}{l}\text { Fear or inadequate abilities prevent starting a new } \\
\text { business }\end{array}$} & \multirow{2}{*}{ FRFAIL } & 0: No \\
\hline & & & 1: Yes \\
\hline \multirow{2}{*}{6} & \multirow{2}{*}{ Prefer a similar standard of living for everyone- } & \multirow{2}{*}{ EQUALI } & 0: No \\
\hline & & & 1: Yes \\
\hline \multirow{2}{*}{7} & \multirow{2}{*}{$\begin{array}{l}\text { Starting one's own business as a desirable career } \\
\text { choice }\end{array}$} & \multirow{2}{*}{ NBGOOD } & $0:$ No \\
\hline & & & 1: Yes \\
\hline \multirow{2}{*}{8} & \multirow{2}{*}{$\begin{array}{l}\text { People who start their business have a high level of } \\
\text { status and respect }\end{array}$} & \multirow{2}{*}{ NBSTAT } & $0:$ No \\
\hline & & & 1: Yes \\
\hline \multirow{2}{*}{9} & \multirow{2}{*}{$\begin{array}{l}\text { Regular coverage stories about successful new } \\
\text { businesses in the public media }\end{array}$} & \multirow{2}{*}{ NBMEDI } & $0:$ No \\
\hline & & & 1: Yes \\
\hline 10 & Shut down a business during the previous year, and & DISCFN & 0: No \\
\hline 10 & never resumed it & DISCEN & 1: Yes \\
\hline 11 & Expectation to start a new business over the next & FUTTSUP & 0: No \\
\hline 11 & three years & FUISUP & 1: Yes \\
\hline & & & 1: Yes, all customers think so \\
\hline 12 & $\begin{array}{l}\text { Offering a product (service) that is new or } \\
\text { unfamiliar to customers }\end{array}$ & SUNEWCST & 2: Yes, some customers think so \\
\hline & & & 3: No, everybody knows about this product or service \\
\hline
\end{tabular}

The timeframe of the study was determined by its main objective: to examine the specific features of early-stage entrepreneurs' choice of funding sources when affected by the economic and social change engendered by the global crisis (while keeping in mind the period of Russia's participation in the GEM project).

Of all the countries taking part in the GEM, the CEE nations were chosen for international comparison: they, like Russia, have gone through a planned economy followed by a period of market reforms accompanied by institutional and social transformations. We managed to ensure the necessary completeness, adequacy, and quality of the microdata for a comparative analysis of seven countries: Russia, Hungary, Romania, Latvia, Croatia, Slovenia, and Bosnia and Herzegovina. Logical and content control was applied to make sure that the early-stage entrepreneurs' sample included only the respondents who answered the GEM questionnaire's questions (the ones who were unable or refused to answer were eliminated). The final sample included 2,360 observations: 167 for Russia, 377 for Hungary, 232 for Romania, 604 for Latvia, 248 for Croatia, 372 for Slovenia, and 360 for Bosnia and Herzegovina.

Each of the early-stage entrepreneurs' answers were analyzed using target indicators describing their attitude toward borrowed capital, and factors potentially affecting the choice of funding sources. Thus, to check the proposed hypotheses, all classifying variables were excluded from the more than 200 indicators in the GEM database (including filters for the stage of the established business), together with variables that had no valid values. The list of indicators selected for analysis (except the classifying variable "Country" described above) is presented in Table 2.

The factors affecting early-stage entrepreneurs' choice of investment sources were determined using Fisher's linear discriminant analysis model (FLDA). This is a multidimensional statistical analysis technique that allows one to build a non-parametric predictive model of the discriminant function. Using 
certain attributes (such as the values of the control variables) this model allows one to verify whether or not the observed objects (in this case, early-stage entrepreneurs) belong to specific predetermined groups. The model's non-parametric nature allows one to apply the FLDA in its original form to distribute objects or events between previously defined groups [Fisher, 1936; McLachlan, 2004]. In a two-dimensional characteristic space, the separating surface is a direct line, building the discriminant function $d$, which describes the required surface separating the specified classes on the basis of the values of the predictor variables, would serve as the core of the discriminant analysis. The function has the following form:

$d=b_{1} \times x_{1}+b_{2} \times x_{2}+\ldots+b_{n} \times x_{3}+a$

where: $x_{1}, x_{2}, \ldots, x_{n}$ are values of the variables corresponding to the units in question;

$b_{1}, b_{2}, \ldots, b_{n}$ are the coefficients measured by the FLDA model; and

$a$ is a constant.

According to the general FLDA concept, the discriminant function was built upon the basis of the values of predictor variables describing the set of observed objects whose membership in specific groups is known ("training sample"). Then the model was verified using a control sample. In our case, a stratified sliding control was applied for verification, which allowed us to reduce the dispersion of the final assessments and build more stable and reliable predictive models [McLachlan, 2004; Efron, 1988]. The resulting discriminant function (sufficiently stable and adequately predictive) allowed us to include previously unclassified individuals in specific groups. We analyzed two groups of respondents: those choosing between their own and borrowed resources as the funding source for their business. A single discriminant function can be built in this case. Based on its calculated values (the so-called discriminant scores), the probability of unclassified objects' belonging to one or another group is determined [Bühl, Zöfer, 2001; Nasledov, 2011]. The quality of the discriminant function was tested using Wilks' Lambda $\left(\lambda_{\mathrm{w}}\right)$, which describes the share of function value dispersion not due to the differences between the respondent groups. The closer $\lambda$ w's value is to zero, the larger the difference between the average values, and accordingly, the higher is this variable's importance for determining the difference between the earlystage entrepreneur groups in question. The significance of the identified differences between the average values for the groups ( $\mathrm{p}$-value $<0.05)$ confirmed that they were not random. The predictive potential of the constructed models was measured by the share of units in the control sample whose membership in a specific group was predicted accurately. It was measured using the accuracy rate (AR), true positive rate (TPR), true negative rate (TNR), and predictability indicators [Fawcett, 2006; Powers, 2011]. The FLDA model-based analysis was conducted in several stages:

- Splitting the array of microdata by the "Country" variable which had seven values (to build a model predicting early-stage entrepreneurs' choice of funding source in specific national contexts)

- Testing the significance of the differences between the predictor variables' values determined for their the two respondent groups (those opting for their own or borrowed resources)

- Building country-specific models distinguishing between specific features of the units being classified, which determine the respondents' membership in one of the two above groups

- Assessing the significance, quality, and predictive potential of the models

- Conducting a comparative analysis of the statistical structure of the constructed models; checking the hypotheses and comparing the various factors' impact on early-stage entrepreneurs' choice of funding sources in different countries in specific national contexts.

The calculations were made using the SPSS-19 software package.

\section{Results of modeling early-stage entrepreneurs' financial choices}

After splitting the prepared microdata matrix on the basis of the national context, differences between the average values of the expected predictors for the two early-stage entrepreneur groups (those opting for their own or borrowed financial resources) were assessed for each of the seven country subsets. The aggregated results of testing the differences between the countries and indicators with significant mismatches between these groups are presented in Table 3 .

Variables, for which there are differences between the group average values for specific countries, were not random with a probability close to 1 (p-value $<0.05$ ). These factors affect early-stage entrepreneurs' choice of funding sources in the corresponding countries. For each controlled variable, the $\lambda w$ value does not indicate a statistically significant contribution of relevant differences between the groups to the overall dispersion of the discriminant function's scores. An international comparison of the statistical structure of the sets of variables, which significantly differ between the respondent groups, confirms that the national socioeconomic context does indeed define specific factors (their mix and variety) affecting 


\section{Table 3. Results of the group mean values equality test}

\begin{tabular}{|c|c|c|c|c|c|c|c|c|c|c|}
\hline \multirow{2}{*}{ Countries } & \multirow{2}{*}{ Indicator } & \multicolumn{9}{|c|}{ Predictor } \\
\hline & & 1 & 2 & 3 & 4 & 5 & 6 & 7 & 8 & 9 \\
\hline \multirow{2}{*}{ Russia } & $\lambda w$ & & & & & & & & 0.846 & \\
\hline & $\mathrm{p}$-value & & & & & & & & 0.020 & \\
\hline \multirow{2}{*}{ Hungary } & $\lambda w$ & & & 0.920 & & & & & & \\
\hline & $\mathrm{p}$-value & & & 0.004 & & & & & & \\
\hline \multirow{2}{*}{ Romania } & $\lambda w$ & & & & & 0.636 & & & & 0.497 \\
\hline & $\mathrm{p}$-value & & & & & 0.002 & & & & 0.007 \\
\hline \multirow{2}{*}{ Latvia } & $\lambda w$ & & & & & & 0.926 & & 0.960 & \\
\hline & $\mathrm{p}$-value & & & & & & 0.016 & & 0.035 & \\
\hline \multirow{2}{*}{ Croatia } & $\lambda w$ & & 0.854 & & & & 0.800 & & & 0.936 \\
\hline & $\mathrm{p}$-value & & 0.006 & & & & 0.002 & & & 0.037 \\
\hline \multirow{2}{*}{ Slovenia } & $\lambda w$ & & & & & 0.891 & & & & \\
\hline & $\mathrm{p}$-value & & & & & 0.002 & & & & \\
\hline \multirow{2}{*}{ Bosnia and Herzegovina } & $\lambda w$ & 0.893 & & & 0.731 & & 0.639 & 0.675 & & 0.789 \\
\hline & & 0.001 & & & 0.000 & & 0.000 & 0.000 & & 0.000 \\
\hline
\end{tabular}

Predictors:

1 - Shut down one's business during the previous year, and never restarted the enterprise

2 - Expectation to start a new business over the next three years

3 - Know somebody personally who started a business over the last two years

4 - People who start their own business have a high level of status and respect

5 - Regular coverage about successful new businesses in the media

6 - Offering a product (service) that is new or unfamiliar to customers

7 - Starting one's own business as a desirable career choice

8 - Expect favourable conditions for starting one's own business to be in place in the area of residence over the next six months

9 - Fear of failure or lack of competencies as barriers to starting one's own business

Source: calculated by the authors.

financial choices. This means that, in transitional economies, none of the predictors noted in the literature affect early entrepreneurs' financial choice. Therefore, we must identify latent factors manifesting as country-specific combinations of the controlled variables. Thus, our first hypothesis is confirmed.

At the next stage, discriminant function models were built for Russia and CEE countries, which allowed for predicting early entrepreneurs' choice of funding sources in the socioeconomic context of their country of residence. All the constructed models were significant; the normalized discriminant function predictors' coefficients allowed us to establish the direction and estimate the force of the corresponding predictor's impact on the financial choice of the early entrepreneurs, and therefore interpret the model (Table 4).

In the end, the factors increasing the probability of early-stage entrepreneurs opting for the use of borrowed resources were identified for each country:

Russia: there are expectations that in the next six months conditions for starting one's own business will improve (and if the prospects for business conditions are perceived negatively, the above probability

\section{Table 4. Normalized coefficients and significance of the discriminant functions}

\begin{tabular}{|c|c|c|c|}
\hline No. & Country & Fisher's linear discriminant * & p-value \\
\hline 1 & Slovenia & OwnF_BorrF $=-2.314+3.928 \cdot \mathrm{NBMEDI}$ & 0.002 \\
\hline 2 & Hungary & OwnF_BorrF $=-2.657+4.388 \cdot \mathrm{KNOWEN}$ & 0.004 \\
\hline 3 & Russia & OwnF_BorrF $=-0.922+1.428 \cdot$ OPPORT & 0.020 \\
\hline 4 & Romania & OwnF_BorrF $=-2.347+3.804 \cdot$ FRFAIL+ 1.391·NBMEDI & 0.000 \\
\hline 5 & Latvia & OwnF_BorrF $=-5.530+4.118 \cdot$ SUNEWCST $+1.438 \cdot$ OPPORT & 0.016 \\
\hline 6 & Croatia & OwnF_BorrF $=-11.310+6.822 \cdot S U N E W C S T+4.597 \cdot F U T S U P+1.786 \cdot F R F A I L$ & 0.002 \\
\hline 7 & $\begin{array}{l}\text { Bosnia and } \\
\text { Herzegovina }\end{array}$ & $\begin{array}{l}\text { OwnF-BorrF }=-9.469+5.155 \cdot \mathrm{DISCEN}+4.116 \cdot \mathrm{SUNEWCST}+3.302 \cdot \mathrm{FRFAIL}+ \\
+3.298 \cdot \mathrm{NBSTAT}+2.547 \cdot \mathrm{NBGOOD}\end{array}$ & 0.000 \\
\hline
\end{tabular}

* Country models in the table are sorted first by complexity of the discriminant's statistical structure (in ascending order), and then by significance of the discriminant function (in descending order).

Source: calculated by the authors. 
Table 5. Quality of CEE transitional economies' early-stage entrepreneurs' classifications based on the FLDA models

\begin{tabular}{|l|c|c|c|}
\hline \multicolumn{1}{|c|}{ Country } & $\begin{array}{c}\text { Accuracy } \\
\text { (AR - share of correctly } \\
\text { classified observations in the } \\
\text { population, \%) }\end{array}$ & $\begin{array}{c}\text { Sensibility, a } \\
\text { (TPR - share of truly positive } \\
\text { classification results in the } \\
\text { population, \%) }\end{array}$ & $\begin{array}{c}\text { Specificity, } \boldsymbol{\beta} \\
\text { (TNR - share of truly negative } \\
\text { classification results in the } \\
\text { population, \%) }\end{array}$ \\
\hline Russia & 61.5 & 9.02 & 52.46 \\
\hline Hungary & 58.9 & 8.93 & 12.3 \\
\hline Romania & 51.9 & 30.23 & 39.86 \\
\hline Latvia & 59.5 & 38.26 & 29.35 \\
\hline Croatia & 69.4 & 9.27 & 31.29 \\
\hline Slovenia & 57.7 & 39.23 & 48.41 \\
\hline $\begin{array}{l}\text { Bosnia and } \\
\text { Herzegovina }\end{array}$ & 70.1 & 31.54 \\
\hline Source: calculated by the authors. & & & 37 \\
\hline
\end{tabular}

drops practically to zero). The same applies to Latvia, where plans to implement an innovative business idea and supply products or services that are new to the market can serve as an additional incentive.

Hungary: there is active involvement of potential businessmen in the social networks of entrepreneurs who have started their own firm over the previous two years.

Slovenia: a positive image of entrepreneurship is promoted by the local media, which regularly covers success stories of new business projects. The same factor also applies in the case of Romania, and its impact outweighs the fears of possible business failure.

Croatia: entrepreneurs have plans to start an innovative business over the next three years, despite the risk of failure. Consumers' intentions make the biggest contribution to the discriminant function.

Bosnia and Herzegovina: five combined factors affect early-stage entrepreneurs' financial choices here. The primary one is having had the experience of liquidating a business over the last year. The probability under consideration also increases if people, who have successfully started a new business, enjoy increasing public recognition and acquire a high social status, while society becomes convinced that entrepreneurship is a desirable career choice. Finally, the willingness to launch, despite the risk of failure, the production of innovative goods or services previously absent on the market also plays a positive role. In other words, Hypotheses 2-4, which imply a positive correlation between the relevant factors and early-stage entrepreneurs' choice in favor of borrowed funding, turned out to be correct in the following cases:

- Hypothesis 2 (favorable conditions for starting one's own business): in Russia and Latvia

- Hypothesis 3 (an innovative business idea): in Latvia, Croatia, and Bosnia and Herzegovina; note that in the two latter cases this factor's impact outweighs fears of possible failure;

- Hypothesis 4 (the promotion of a positive image of entrepreneurship in the media): in Slovenia and Romania.

The predictive potential of the constructed country-specific discriminant models, i.e. their ability to break early-stage entrepreneurs down into those willing and those unwilling to use borrowed money on the basis of the canonical functions, was measured on the basis of the following integral characteristics (Table 5).

As we see, the models' diagnostic efficiency is quite high, though their sensitivity is significantly lower than their specificity. Therefore, the suggested models should be used as discriminators, i.e., tests for identifying early-stage entrepreneurs who prefer to fund their businesses with their own resources.

The prognostic value of the constructed models is limited by the predominance of one's own funds (including "love capital") in early-stage entrepreneurs' portfolio (Table 5). Therefore, the more specific the model, the higher the prognostic value possessed by the positive results (i.e., the probability that the early-stage entrepreneur's predicted willingness to use borrowed capital turns out to be actually true). However, since the prevalence of a phenomenon affects the model's predictive value, the positive results obtained even for a highly specific discriminator, given the low share of borrowed resources in earlystage entrepreneurs' capital structure, can be perceived as a false positive.

Given the stated objective of the study, the results appear quite satisfactory. All hypotheses were confirmed in one national context or another, which is important from the point of view of developing specific approaches to the promotion and support of entrepreneurship. Furthermore, the prognostic value of the models turned out to be sufficiently high. 


\section{Table 6. Prognostic value of the classification models based on the constructed discriminant functions}

\begin{tabular}{|l|c|c|}
\hline Country & $\begin{array}{c}\text { Prognostic value of positive results (the share of } \\
\text { truly positive results in the total number of positive } \\
\text { classification results, \%) }\end{array}$ & $\begin{array}{c}\text { Prognostic value of negative results (the share of } \\
\text { truly negative results in the total number of negative } \\
\text { classification results, \%) }\end{array}$ \\
\hline Russia & 57.89 & 62.14 \\
\hline Hungary & 36.47 & 66.03 \\
\hline Romania & 65.71 & 48.68 \\
\hline Latvia & 59.09 & 60.32 \\
\hline Croatia & 75.0 & 64.29 \\
\hline Slovenia & 50.0 & 59.31 \\
\hline $\begin{array}{l}\text { Bosnia and } \\
\text { Herzegovina }\end{array}$ & 78.46 & 63.08 \\
\hline Source: calculated by the authors. & \\
\hline
\end{tabular}

\section{Conclusions and recommendations}

In each country, the transitional economy is unique, with specific characteristics and conditions that affect the development path and drivers of entrepreneurship. These in turn determine early-stage entrepreneurs' attitude towards various funding sources. Therefore, the same measures aimed at supporting entrepreneurship can cause different reactions by the target communities depending on the country-specific context.

The situation with the structure of early-stage entrepreneurs' financial capital is particularly critical: the inclination to avoid official loans slows down the development of entrepreneurship in Russia, while the availability of "love capital" only aggravates the problem. At the same time, the simple duplication of entrepreneurship support arrangements that were successfully implemented in other countries and regions may have undesirable negative effects in the Russian economic environment. Specific features of entrepreneurial practices in the country must be carefully taken into account, based on published statistics and special population surveys of entrepreneurial activities. Providing information support to the designers of entrepreneurship promotion policies would help them suggest specific steps to increase the efficiency of funding programs for early-stage entrepreneurship.

The legal environment for entrepreneurship needs to be stabilized, made more transparent and comfortable in terms of new entrepreneurs' prospects; business support should be individualized, especially at the early stages (until companies reach three and half years of operation). This would help all early-stage entrepreneurs feel protected, and assess their business prospects as favorable.

Keeping in mind the results obtained for transitional economies, improving Russia's business climate should first of all involve promoting innovative entrepreneurial behavior among the general population. Relevant tools may include idea fairs, exhibitions of innovative products, and consumers' suggestions (the municipal and local authorities seem to be best suited for the task of analyzing and presenting these proposals). The promotion of innovation could help early-stage entrepreneurs overcome the fear of failure, a lack of self-confidence, and the negative experiences of previous business failures.

Finally, mass media could and should provide effective information support to early-stage entrepreneurs, and help them find their way in the relevant environment. Promoting a new, positive image of entrepreneurship in the public conscience, presenting (and helping people see) it as a desirable career choice could extend the range of factors prompting early-stage entrepreneurs to optimize the financial structure of their capital.

Generally, the results of our analysis suggest the possibility of applying individual approaches to designing entrepreneurship support policies in Russia and CEE countries. Optimizing early-stage entrepreneurs' funding choices (including when they are faced with expensive loans), and increasing the appeal of borrowed financial resources would help promote the development of the entrepreneurial sector, and make it more innovative. 


\section{References}

Aidis R. (2005) Entrepreneurship in transition countries: A review (UCL School of Slavonic and East European Studies Working Paper no 61, December), London: University College London.

Antoniou A., Guney Y., Paudyal K. (2008) The Determinants of Capital Structure: Capital Market-oriented versus Bank-oriented Institutions. Journal of Financial and Quantitative Analysis, vol. 43, no 1, pp. 59-92.

Audretsch D., Thurik R. (2004) A Model of the Entrepreneurial Economy. International Journal of Entrepreneurship Education, vol. 2, no 2, pp. 143-166.

Beck T., Demirguc-Kunt A., Maksimovic V. (2008) Financing Patterns around the World: Are Small Firms Different? Journal of Financial Economics, vol. 89, no 3, pp. 467-487.

Berger A., Christa H.S., Bouwman T.K., Schaeck K. (2010) Bank liquidity creation and risk taking during distress (Discussion Paper Series 2, no 05/2010), Berlin: Deutsche Bundesbank.

Black L.K. (2009) Information Asymmetries between Lenders and the Availability of Competitive Outside Offers. Paper presented at the Workshop on Entrepreneurial Finance hosted by the Federal Reserve Bank of Cleveland and Kauffman Foundation, Cleveland, OH, March 2009.

Bühl A., Zöfel P. (2001) SPSS version 10. Einführung in die modern Datenanalyse unter Windows. München: Pearson Education Deutschland GmbH.

Chavis L., Klapper L., Love I. (2011) The Impact of the Business Environment on Young Firm Financing. The World Bank Economic Review, vol. 25, no 3, pp. 486-507.

Djankov S., Murrell P. (2002) Enterprise Restructuring in Transition: A Quantitative Survey. Journal of Economic Literature, vol. 40, no 3, pp. 739-793.

Efron B. (1988) Netraditsionnye metody mnogomernogo statisticheskogo analiza [Non-traditional methods of multivariate statistical analysis], Moscow: Finansy i statistika (in Russian).

Fawcett T. (2006) An Introduction to ROC Analysis. Pattern Recognition Letters, vol. 27, no 8, pp. 861-874. DOI:10.1016/j.patrec.2005.10.010.

Fisher R.A. (1936) The use of multiple measurements in taxonomic problems. Annals of Eugenics, vol. 7, pp. $179-188$.

GERA (2017) GEM Global Report 2016/17, London: Global Entrepreneurship Research Association.

Gerasimova S.M. (2012) Empiricheskie issledovaniya struktury kapitala kompanii na razvivayushchikhsya rynkakh: spetsifika i metodologiya [Empirical Investigations of the Capital Structure of Companies in Emerging Markets: Specificity and Methodology]. Korporativnye finansy [Journal of Corporate Finance Research], vol. 6, no 1, pp. 97-109 (in Russian).

Glas M., Drnovsek M., Mirtic D. (2000) Problems faced by new entrepreneurs: Slovenia and Croatia - A Comparison. Paper presented at the 30th ESBS Seminar, Gent.

Hashi I. (2001) Financial and Institutional Barriers to SME Growth in Albania: Results of an Enterprise Survey. MOST, vol. 11, pp. 221-238.

Holm S. (1979) A simple sequentially rejective multiple test procedure. Scandinavian Journal of Statistics, vol. 6, no 2, pp. 65-70.

Klapper L., Laeven L., Rajan R. (2006) Barriers to Entrepreneurship. Journal of Financial Economics, vol. 82, no 3, pp. 591-629.

Levine R. (2005) Finance and Growth: Theory and Evidence. Handbook of Economic Growth (eds. P. Aghion, S. Durlauf), Amsterdam: Elsevier, pp. 865-934.

McLachlan G.J. (2004) Discriminant Analysis and Statistical Pattern Recognition, Hoboken, NJ: Wiley Interscience.

Murzacheva E. (2011) The input of informal capital into the entrepreneurial activity in the international context. Theory of Entrepreneurship: New Results and Prospects (Research papers) (ed. A. Chepurenko), Moscow: HSE Publishing, pp. 103-135.

Murzacheva E.I., Obraztsova O.I. (2008) Neformal'nye investory kak osnovnye sponsory rossiiskogo narozhdayushchegosya predprinimatel'stva: vybor v usloviyakh dorogogo kredita [Informal investors as the main sponsors of Russian nascent entrepreneurship: Choice under conditions of an expensive loan]. Finansy $i$ biznes [Finance and Business], no 3, pp. 145-153 (in Russian).

Nasledov A. (2011) SPSS 19: Professional'nyi statisticheskii analiz dannykh [SPSS 19: Professional statistical analysis of data], SPb.: 'Piter' (in Russian).

Obraztsova O.I. (2010) GEM kak istochnik al'ternativnoi statistiki dlya sravnitel'nogo mezhstranovogo analiza predprinimatel'skoi aktivnosti [GEM as a source of alternative statistics for a comparative cross-country analysis of entrepreneurial activity]. Teoriya predprinimatel'stva $v$ Rossii. Po materialam Global'nogo monitoringa predprinimatel'stva [Theory of Entrepreneurship in Russia. On the basis of the Global Monitoring of Entrepreneurship] (eds. T.A. Alimova, O.I. Obraztsova, A.Yu. Chepurenko), Moscow: HSE Publishing, pp. 18-62 (in Russian).

Powers D.M.W. (2011) Evaluation: From Precision, Recall and F-Measure to ROC, Informedness, Markedness \& Correlation. Journal of Machine Learning Technologies, vol. 2, no 1, pp. 37-63.

Reynolds P., Bosma N., Autio E. (2005) Global Entrepreneurship Monitor: Data Collection Design and Implementation 1998-2003. Small Business Economics, vol. 24, no 3, pp. 205-231.

Robb A., Robinson D. (2010) The Capital Structure Decisions of New Firms (NBER Working Paper no 16272), Cambridge, MA: National Bureau of Economic Research.

Shane S., Venkataraman S. (2000) The Promise of Entrepreneurship as a Field of Research. The Academy of Management Review, vol. 25, no 1, pp. 217-226.

Verheul I., Thurik R. (2001) Start-Up Capital: Does Gender Matter? Small Business Economics, vol. 16, no 4, pp. 29-45.

Welter F. (2011) Contextualizing Entrepreneurship - Conceptual Challenges and Ways Forward. Entrepreneurship Theory and Practice, vol. 35, no 1, pp. 165-184.

Welter F., Smallbone D. (2011) Institutional Perspectives on Entrepreneurial Behavior in Challenging Environments. Journal of Small Business Management, vol. 49, no 1, pp. 107-125.

Yang J.S., Kuntchev V., Ramalho R., Rodriguez-Meza J. (2013) What have we learned from the Enterprise Surveys regarding access to finance by SMEs? Policy Research Working Paper WPS6670. Washington, D.C.: World Bank. 